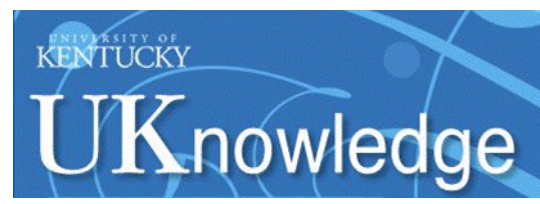

University of Kentucky UKnowledge

$5-5-2014$

\title{
Amino Acid Racemase Enzyme Assays
}

Atanas D. Radkov

University of Kentucky, a.radkov@gmail.com

Luke A. Moe

University of Kentucky, luke.moe@uky.edu

Follow this and additional works at: https://uknowledge.uky.edu/pss_facpub

Part of the Biochemistry Commons, and the Microbiology Commons

Right click to open a feedback form in a new tab to let us know how this document benefits you.

\section{Repository Citation}

Radkov, Atanas D. and Moe, Luke A., "Amino Acid Racemase Enzyme Assays" (2014). Plant and Soil Sciences Faculty Publications. 123.

https://uknowledge.uky.edu/pss_facpub/123

This Article is brought to you for free and open access by the Plant and Soil Sciences at UKnowledge. It has been accepted for inclusion in Plant and Soil Sciences Faculty Publications by an authorized administrator of UKnowledge. For more information, please contact UKnowledge@lsv.uky.edu. 


\section{Amino Acid Racemase Enzyme Assays}

Digital Object Identifier (DOI)

https://doi.org/10.21769/BioProtoc. 1112

\section{Notes/Citation Information}

Published in Bio-protocol, v. 4, issue 9, p. 1-5.

Copyright $\odot 2014$ The Authors; exclusive licensee Bio-protocol LLC.

The publisher has granted the permission for posting the article here. 


\section{Amino acid Racemase Enzyme Assays}

Atanas D. Radkov and Luke A. Moe*

Department of Plant and Soil Sciences, University of Kentucky, Lexington, USA

*For correspondence: luke.moe@uky.edu

[Abstract] Amino acid racemases are enzymes that invert the $\alpha$-carbon stereochemistry of amino acids (AAs), interconverting amino acids between their L- and D-enantiomers in a reversible reaction. In bacteria, they are known to have catabolic physiological functions but are also involved in the synthesis of many D-AAs, including D-glutamate and D-alanine, which are necessary components of the peptidoglycan layer of the bacterial cell wall. As such, amino acid racemases represent significant targets for the development of bactericidal compounds. Amino acid racemases are also regarded by the biotechnological industry as important catalysts for the production of economically relevant D-AAs. Here, we provide a detailed protocol using high performance liquid chromatography (HPLC) and 1-fluoro-2,4-dinitrophenyl-5-L-alanine amide (FDAA, also Marfey's reagent) for the characterization of novel amino acid racemases. The protocol described here was designed to obtain accurate kinetic parameters ( $k_{c a t}, K_{M}$ values). Enzyme concentrations and reaction times were optimized so as to minimize the reverse reaction, which can confound results when measuring racemase reactions.

\section{Materials and Reagents}

1. Escherichia coli (E. coli) Rosetta 2 (DE3) cell line

2. $\mathrm{pET}$ overexpression system

3. His-tag and $\mathrm{Ni}^{2+}-\mathrm{NTA}$ affinity chromatography (HIS-Select Nickel Affinity Gel) (SigmaAldrich, catalog number: P6611)

4. AA substrates

Note: Each enantiomer of the 19 chiral proteinogenic AAs, and the four epimers of hydroxyproline, are prepared in 50 mM HEPES buffer ( $\mathrm{pH}$ 7.4) with any co-factors (PLP at $20 \mu \mathrm{M}$ was used in our case).

5. $0.5 \%$ solution ( $w / v$, in acetone) of Marfey's reagent (Sigma-Aldrich, catalog number: 71478) $1 \mathrm{M} \mathrm{NaHCO}_{3}$

6. $2 \mathrm{M} \mathrm{HCl}$

7. $2 \mathrm{M} \mathrm{NaOH}$

8. HPLC buffer (0.05 M TEAP buffer, pH 3.0) (see Recipes) 


\section{Equipment}

1. Bottle top filter (polystyrene) (Corning, catalog number: 430513) (filter used in TEAP buffer preparation)

2. Syringe filter (PTFE) (Tisch Scientific, catalog number: SF14466) (filter used in HPLC sample preparation)

3. Heat block (set at $37^{\circ} \mathrm{C}$ for enzyme reactions)

4. Heat block (set at $40{ }^{\circ} \mathrm{C}$ for derivatization of reaction products)

5. $2 \mathrm{ml}$ microfuge tubes (for the reaction, derivatization, and dilution of derivatized products)

6. Amber HPLC vials with caps, syringes $(1 \mathrm{ml})$, needles, and filters $(0.22 \mu \mathrm{m}$ polytetrafluoroethylene, PTFE)

7. Waters Nova-Pak ( $\mathrm{C}_{18}$ column $)(3.9 \mathrm{~mm}$ by $150 \mathrm{~mm})$

\section{Software}

1. Microsoft Excel

\section{Procedure}

A. Enzyme preparation and storage

1. Enzyme was overexpressed using E. coli Rosetta 2 (DE3) cell line and the pET overexpression system, His-tag and $\mathrm{Ni}^{2+}$-NTA affinity chromatography [for specifics, please see Goodlett et al.(1995)].

2. After chromatography and buffer exchange, the enzyme was divided into $50 \mu$ aliquots and was snap-frozen before long-term storage at $-80^{\circ} \mathrm{C}$.

B. Enzyme assays

1. Enzyme reactions were performed in $2 \mathrm{ml}$ microfuge tubes.

2. $199 \mu \mathrm{l}$ of AA solution in $50 \mathrm{mM}$ HEPES ( $\mathrm{pH}$ 7.4) plus cofactors (if needed) were placed in each reaction tube.

a. $20 \mu \mathrm{M}$ pyridoxal-5'-phosphate (PLP) was added based on bioinformatic evidence that the enzyme has a PLP-binding motif.

3. To pre-condition the assay solution, the assay tubes were kept at $37^{\circ} \mathrm{C}$ for 5 min before enzyme addition.

4. Assay was initiated by the addition of the purified enzyme to a final volume of $200 \mu$ l.

a. The final enzyme concentration was determined empirically and varied based on the particular substrate used. In our case, between $1 \mu \mathrm{M}$ and $2 \mu \mathrm{M}$ final enzyme 
concentrations were used to determine relative substrate specificity, and between 1 $\mathrm{nM}$ and $2 \mu \mathrm{M}$ - to calculate the enzyme kinetics. For further specifics, please see Goodlett et al. (1995).

b. The molar concentration of enzyme used was kept at $10 \%$ or less of the initial substrate concentration.

5. Assay was performed at $37^{\circ} \mathrm{C}$ for $1 \mathrm{~min}$.

a. The assay duration was chosen so that only $10 \%$ or less of the initial substrate was consumed in order to minimize the occurrence of the reverse reaction.

6. To quench the assay, $40 \mu \mathrm{l}$ of $2 \mathrm{M} \mathrm{HCl}$ was added and mixed by pipetting.

7. In preparation for derivatization, $40 \mu \mathrm{l} 2 \mathrm{M} \mathrm{NaOH}$ was added to neutralize the acid.

8. $50 \mu \mathrm{l}$ of the neutralized, quenched assay was transferred to a new $2 \mathrm{ml}$ microfuge tube.

9. $100 \mu \mathrm{l}$ of $0.5 \%$ Marfey's reagent in acetone was added.

10. $20 \mu \mathrm{l}$ of $1 \mathrm{M} \mathrm{NaHCO}_{3}$ was added to make the solution alkaline, and the contents were mixed via pipetting.

11. Derivatization was performed on a heat block at $40{ }^{\circ} \mathrm{C}$ for $1 \mathrm{~h}$.

a. During this time, fresh $1 \mathrm{~L} \mathrm{HPLC}$ buffer was prepared and passed through $0.22 \mu \mathrm{m}$ bottle top filter every time before sample analysis.

b. Also, $900 \mu \mathrm{l}$ of $80 \% 0.05 \mathrm{M}$ TEAP buffer ( $\mathrm{pH} 3.0$ ) and $20 \%$ acetonitrile (HPLC grade) was placed in new $2 \mathrm{ml}$ microfuge tubes in preparation for the 10-fold dilution of the derivatized products.

12. Derivatization reaction was briefly centrifuged to collect any condensation from the lid of the microfuge tube.

13. Reaction was cooled at room temperature for $5 \mathrm{~min}$.

14. $100 \mu \mathrm{l}$ of the reaction was mixed with the solution in step B11b to prepare a 10-fold dilution.

15. The diluted derivatization reaction was passed through a PTFE $0.22 \mu \mathrm{m}$ syringe filter and placed into an amber HPLC vial.

a. Derivatization reactions should be kept in an amber vial to prevent photochemical decomposition of the absorbing chromophore (Marfey, 1984). In our case, assays were analyzed within $48 \mathrm{~h}$ after derivatization.

16. The same procedure as above was followed (the enzyme addition was omitted.) to determine AA elution times and prepare standard curves.

C. HPLC analysis

1. The specific column employed in our case was Waters Nova-Pak, $\mathrm{C}_{18}$ column.

2. $10 \mu \mathrm{l}$ of the diluted derivatized reaction (from step B15) was analyzed.

3. Flow rate was $0.5 \mathrm{ml} / \mathrm{min}$. 
4. Derivatized products were detected at $340 \mathrm{~nm}$.

5. Several gradients were employed for the separation of different enantiomeric pairs.

a. For a description of the gradients, please refer to the methods section and supplementary material of the original publication by Radkov and Moe (2013).

D. Data analysis

1. Due to differences in the derivatization efficiency between enantiomeric pairs, derivatized D-AAs yield a higher UV response relative to L-AAs. The data provided by Goodlett et al. was used to adjust for these differences before preparing standard curves and calculating specific activities.

a. Example chromatogram

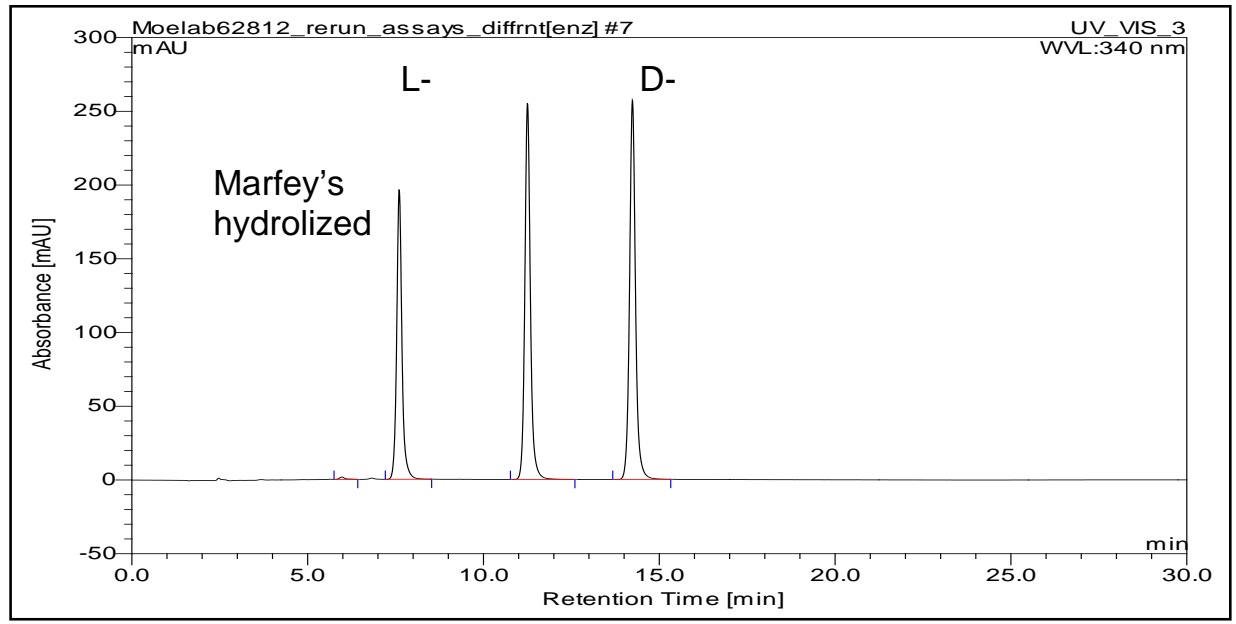

2. The Solver function in Microsoft Excel was used to perform non-linear curve fitting to the Michaelis-Menten equation.

a. An example dataset (attached here) is provided as a supplementary file.

\section{$\underline{\text { Recipes }}$}

1. HPLC buffer (0.05 M TEAP buffer, pH 3.0)

Solution of $0.05 \mathrm{M}$ triethylamine was prepared and the $\mathrm{pH}$ was adjusted using concentrated phosphoric acid.

\section{Acknowledgments}

This protocol was adapted from Radkov and Moe (2013). This work was supported in part by grant 2011-67020-30195 from the USDA National Institute of Food and Agriculture. 


\section{References}

1. Goodlett, D. R., Abuaf, P. A., Savage, P. A., Kowalski, K. A., Mukherjee, T. K., Tolan, J. W., Corkum, N., Goldstein, G. and Crowther, J. B. (1995). Peptide chiral purity determination: hydrolysis in deuterated acid, derivatization with Marfey's reagent and analysis using high-performance liquid chromatography-electrospray ionization-mass spectrometry. J Chromatogr A 707(2): 233-244.

2. Marfey, P. (1984). Determination ofD-amino acids. II. Use of a bifunctional reagent, 1, 5difluoro-2, 4-dinitrobenzene. Carlsberg Res Communi 49(6): 591-596.

3. Radkov, A. D. and Moe, L. A. (2013). Amino acid racemization in Pseudomonas putida KT2440. J Bacteriol 195(22): 5016-5024. 